INSIGHTS INTO REGIONAL DEVELOPMENT

ISSN 2669-0195 (online) http://jssidoi.org/IRD/

2019 Volume 1 Number 4 (December)

http://doi.org/10.9770/IRD.2019.1.4(1)

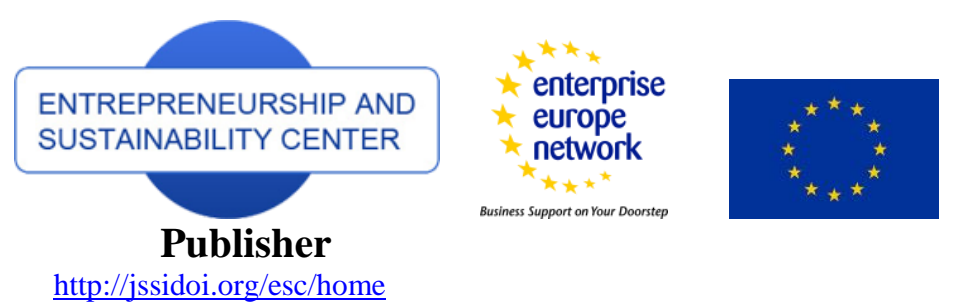

\title{
PUBLIC POLICY FOR HOUSING DEVELOPMENT: A CASE STUDY ON HOUSING DEVELOPMENT IN SEMARANG REGENCY - INDONESIA*
}

\section{Gatot Sasongko', Ina Ariani Restiani Hunga ${ }^{2}$, Ardhian Syah Noer Julana ${ }^{3}$, Yustinus Wahyudi ${ }^{4}$, Paulus Leliak $^{5}$, Andrian Dolfriandra Huruta ${ }^{6 *}$}

\author{
1,2,3,4,5 Satya Wacana Christian University, Faculty of Interdisciplinary, Diponegoro 52-60, Salatiga, Indonesia \\ ${ }^{6}$ Satya Wacana Christian University, Faculty of Economics and Business, Diponegoro 52-60, Salatiga, Indonesia \\ E-mails: ${ }^{1}$ gatot.sasongko@staff.uksw.edu ; ${ }^{2}$ ina.hunga@uksw.edu ; ${ }^{3}$ asnj272@gmail.com ; ${ }^{4}$ ywahyudi2310@gmail.com ; \\ 5leliakpaulus@gmail.com ; ${ }^{*}$ andrian.huruta@staff.uksw.edu (corresponding author)
}

Received 14 May 2019; accepted 20 August 2019; published 15 November 2019

\begin{abstract}
This study aims to describe the implementation of public policy from the perspective of Dye's theory of spatial planning for housing in Semarang Regency. The primary data used in this study were obtained from ten informants as the representatives of each business activity who proposed location permits for housing activities. While the secondary data were obtained from the Public Works Office of Semarang Regency. The results show that there were ten investment activity plans for housing in Semarang Regency, whose proposals were not approved initially by the relevant agencies because they were not in accordance with the provisions of spatial planning. This study provide evidence from ten informants there are eight cases as follows space utilization through a land consolidation program, space utilization in a wide \& river border area, space utilization in vacant spatial planning area, space utilization for communities affected by railroad project, space utilization in spatial planning area of crop farming, space utilization with a housing certificate status, space utilization in plantation planning area, and space utilization in the vacant spatial planning area adjacent to the border of other city administration area. However, after being considered by the government in terms of public policy, the ten location permits were issued with certain conditions. Thus, it could be concluded that the public policy was essentially designed by the government to guarantee and fulfill the needs of the community in conducting investment activities such as housing developers.
\end{abstract}

Keywords: spatial planning; public policy; housing development

Reference to this paper should be made as follows: Sasongko, G., Hunga, I.A.R., Julana, A.S.N. Wahyudi, Y., Paulus Leliak, P., Huruta, A.D. 2019. Public policy for housing development: a case study on housing development in Semarang Regency - Indonesia. Insights into Regional Development, 1(3), 280-300. https://doi.org/10.9770/ird.2019.1.4(1)

JEL Classifications: J68, R14, R21, R58

\section{Introduction}

Globalization as a phenomenon has spread and it brings influences and a variety of impacts on human life in almost all countries, including Indonesia. These changes require the readiness of all national components to deal with it. Currently, Indonesia's economic development is showing an increasing trend along with the growth of the

\footnotetext{
${ }^{*}$ This research was supported by the Ministry of Research and Higher Education of the Republic of Indonesia under 2019Thesis Research Gran
} 


\section{INSIGHTS INTO REGIONAL DEVELOPMENT}

ISSN 2669-0195 (online) http://jssidoi.org/jesi/

2019 Volume 1 Number 4 (December)

http://doi.org/10.9770/IRD.2019.1.4(1)

Asia Pacific region as the center of the world economic growth, where Indonesia is one of the main epicenters in the Southeast Asia region. This momentum requires a well-planned development concept. This also shows the importance of spatial planning so that the development of economic development areas, agriculture, forest conservation and residential areas is well planned.

The growth of Indonesia's population is increasing every year, but it is not followed by an increase in land for housing. Houses are a primary human need. As explained in Law Number 11 of 2011 concerning Housing and Settlement Areas, houses are buildings that function as livable shelter, family building facilities, reflection of the dignity of the inhabitants, and assets for their owners. In the Law, it is also explained that the implementation of housing and settlements includes planning, development, utilization and control activities, including institutional development, funding and financing systems, and the role of coordinated and integrated communities.

Livable shelters are the basic needs of all humans. However, at the moment, there are still many people who are unable to meet those needs. There is a total of 3.4 million non-livable shelters nationwide, where the growth of housing needs is 800.000 per year, and the number of housing needs or backlogs nationwide is 7.6 million (Ministry of Public Works and Housing, 2019). Furthermore, based on home ownership or residential buildings in Indonesia, it was mentioned that of 59.836.906 families, only 46.709 .340 had their own houses, while the rest did not have their own houses or they were in a rent or contract status, hitchhikers and others (Ministry of Public Works and Housing, 2017). The number of housing backlog for people in Central Java Province is still quite high. The backlog, in terms of ownership and occupancy, is different. The Central Java Housing and Settlement Service Office noted that the backlog was divided into ownership of 705.000 housing units, while in terms of occupancy, there were 503.000 housing units spread across 35 regencies or cities (People's Housing and Settlement Areas Agency, 2018). Based on the PBDT (Pemutakhiran Basis Data Terpadu, Integrated Data Base Update), there were non-livable houses of 39.984 units with a priority of 30.731 units located in poor population areas in Semarang Regency (Central Bureau of Statistics, 2018). The authors predict that the causes of housing and settlement problems in Semarang Regency are (1) the development of urban functions centered on certain regions; (2) limited availability of residential land at affordable prices; (3) there are still many people who build residential areas in the areas of plantations, agriculture and even the ones prone to natural disasters; (4) lack of control over the direction of the development of housing and settlement areas; (5) increasing slum area and (6) there is no institution of regional-based housing and settlement development integrated with the Regional Spatial Planning.

Semarang Regency also faces a polemic related to public policy and spatial planning. The problem that always arises in the last five years (2014 until 208) is the overlap of space for one interest in the interests of the other. This happened because of differences in perceptions between the government and the community to a region. However, the facts show that spatial plans are sometimes more likely to side with capital owners or investors. Spatial planning policy is part of the issue where it is related to investment in housing development and there are many licensing requests for housing construction in Semarang Regency. However, referring to the Semarang Regency spatial pattern map in Appendix VI of Regional Regulation Number 6 of 2011, it happens that the location requested is designated as an area for plantation or crop farming. This request was initially not approved, but in the end the permit could be given as recommended by the Spatial Planning Coordinating Board of Semarang Regency. At least, there are 10 (ten) housing activities with such cases (Public Works Agency, 2018). This study refers to previous studies such as those conducted by Seo and Kwon (2017), Antczak (2017), Cesarski (2017), Ogrodowczyk (2015), Musa, Amirudin, Sofield, and Musa (2015), Davy (2014), Cooke and Moon (2015), Cazacova, Erdelhun, Saymanlier, Cazacova, and Ulbar (2010), and Castañeda and Guerrero (2018) which focus on public policy and housing development. Furthermore, this study also refers to studies by McCord et al. (2014), Janssen-Jansen and Lloyd (2012), Holmes (2013), Gerber and Hartmann (2017) which focus on land use policies and ownership rights and researches by Saifullah (2016) and Nasriaty (2016) which focus on spatial planning and settlement development policies. Most of the previous studies explained the role of public policy and the development of housing areas and only a few reviewed policies on spatial planning (control), land use 
(utilization), and ownership rights in the process of sustainable development. This study is important to describe and explain the implementation of public policy from the perspective of Dye's (2002) theory of spatial planning for housing development in Semarang Regency.

\section{Theoretical background and literature review}

Public policy involves three main components: society, political system, and public policy. Dye (2002) illustrates their relation in Figure 1 below.

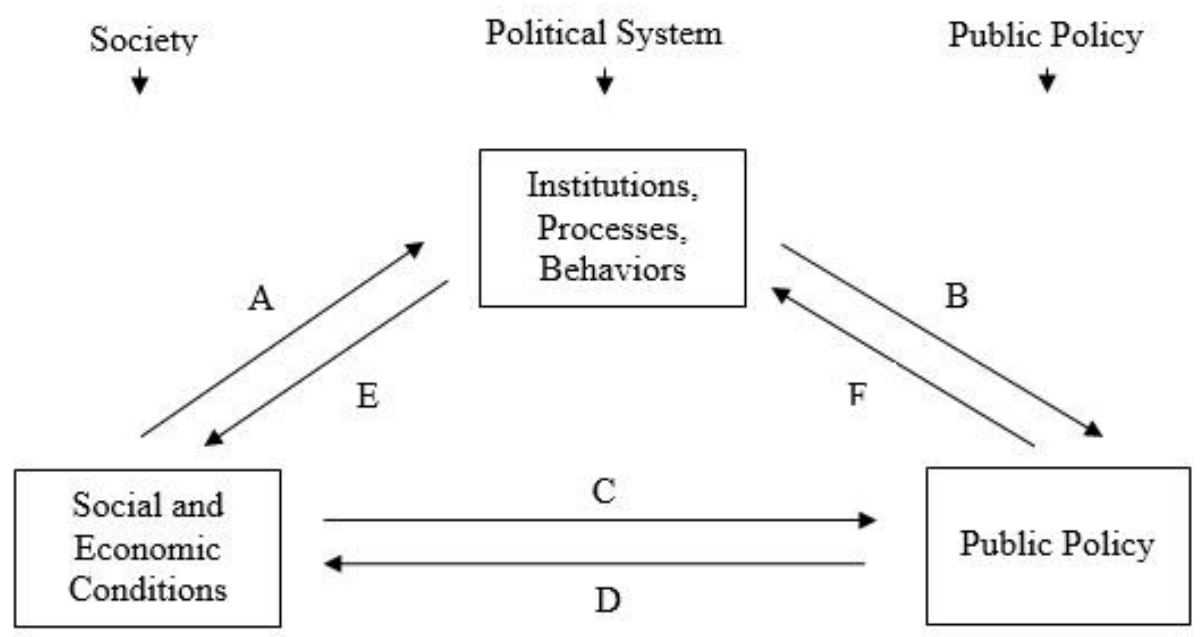

Fig. 1. Sources of Policy: Causes and Consequences Source: Dye (2002)

Figure 1 describes that the socio-economic conditions of the community include welfare (income), inflation, recession, unemployment, education level, environmental quality, poverty, racial groups, religion and ethnicity, life expectancy, inequality and discrimination. Institutions, processes, and behaviors in the political system include federalism, separation of powers, balance of power, party systems, interest groups, voting behavior, bureaucracy, power structures, congresses, presidents, and courts. Public policies resulting from the condition of the community responded to and processed in the political system can be civil rights, education policies, welfare policies, health care policies, criminal justice, taxation, expenditure and budget deficits, defense policies, and regulations. While the arrows shown by line A, B, C, D, E, and F in the figure show the influence of one component on the other components. The Dye policy triangle can also be used to picturize how public policy in Indonesia is designed and implemented. In Indonesia, the determined public policy is influenced by the socioeconomic conditions of the community, both with regard to the level of education, community income, poverty, quality of life, and competitiveness. Indonesian institutional and political systems influence and are influenced by the socio-economic conditions of the Indonesian people. The institutions are very complicated such as the legal, economic, political, and cultural systems.

Literature on public policy and land use for housing has been examined in various parts of the world including Indonesia. In Poland, Antczak (2017) proved that urban areas offered important opportunities for economic development and expand access to basic services such as health, education and housing. Cities in Poland had also noticed the greening of the cities (parks, roads, and areas in residentials, tombs and forests) in the period of 2004 


\section{INSIGHTS INTO REGIONAL DEVELOPMENT}

ISSN 2669-0195 (online) http://jssidoi.org/jesi/

2019 Volume 1 Number 4 (December)

http://doi.org/10.9770/IRD.2019.1.4(1)

until 2015. However, the country still faces obstacles such as uncontrolled urban expansion, poor management and a lack of spatial urban planning systems.

Castañeda and Guerrero (2018) used 79 development indicators from 177 countries to prove that public policy was designed by the government to accelerate economic development. However, the implementation of public policy was faced by obstacles such as natural disasters or political turmoil regularly. This condition prevented the use of resources for infrastructure development (roads, housing and etc.) and labor reform. On the other hand, the dualism between the resilience of policies and policy priorities was also an obstacle to economic development.

In North Cyprus, Cazacova, Erdelhun, Saymanlier, Cazacova, and Ulbar (2010) proved that these days, there had been an increase in the need for housing in urban areas. This indicates that there were attempts to improve the quality of life in urban areas. Improving the quality of life was implemented through the planning and development of residential areas by considering the social and spatial aspects. Public policies taken by the relevant government had considered the advantages and disadvantages aspects of the development of residential areas. This was intended to get a win-win solution for meeting community needs and sustainable development.

In Poland, Cesarski (2017) showed that housing and settlement policies were one of the solutions for people in the urban area. The policy was able to facilitate the existing social, political, economic and ecological relations. This condition ultimately supported the concept of fair housing and sustainable development.

In Australia, Cooke and Moon (2015) revealed that market-based instruments (MBI) became the supporting public policy in dealing with land conversion issues. The developer had the responsibility to pay costs for damages ecologically. On the other hand, this policy was also able to support conservation activities in residential areas.

In Germany, Davy (2014) proved that public policy regarding land use was able to facilitate the issue of land use for housing. This condition was intended to make the land use to start with planning on the positive and negative impacts of developing residential areas.

In Switzerland, Gerber and Hartmann (2017) showed that the land use policies for housing development could guarantee property rights of every community. On the other hand, this policy was also able to control the allocation of land for housing development projects.

In Queensland, Holmes (2013) found that property rights were still a serious problem in the country. In fact, issuing land certificates to build housing often led to problems with environmental management. Therefore, land use policy was an alternative to reconcile the issue.

In Netherlands, United Kingdom and Ireland, Janssen-Jansen and Lloyd (2012) proved that public policies often produced negative effects on land and property rights. As a result, the economic conditions, political priorities and cuts in public spending had created dysfunctional land and property ownership. Therefore, the use of a strategy to reduce the supply of land and property was such a horrible way to overcome market failures.

In the UK, McCord et al. (2014) revealed that the policy of urban green open space had a positive and significant impact on the selling price of property (housing and apartments). This was supported by the existence of land use planning that involved all stakeholders in property taxation.

In Nigeria, Musa, Amirudin, Sofield, and Musa (2015) found that the political, economic and social dimensions influenced the success of public housing projects in developing countries. Thus, the development of a 


\section{INSIGHTS INTO REGIONAL DEVELOPMENT}

ISSN 2669-0195 (online) http://jssidoi.org/jesi/

2019 Volume 1 Number 4 (December)

http://doi.org/10.9770/IRD.2019.1.4(1)

comprehensive model could help housing policy makers, consultants, developers, contractors and other stakeholders for the planning and development of public housing programs.

In Poland, Ogrodowczyk (2015) revealed that the collapse of the regime of socialism produced a major transformation in housing development policies. This was supported by the existence of a separate institution (local government) that regulated the housing development. This means that the state did not participate directly in the process of housing development.

In Vietnam, Seo and Kwon (2017) proved that migration was a driving factor for urban growth. However, housing shortages were becoming a serious problem in urban areas. The Vietnamese government encouraged partnerships with communities and the private sector to provide various types of housing stock. The type of row house in a residential area was highly favored by the majority of the population. However, the preference for apartments was also in demand for future planning. This phenomenon shows that the government must be wise in considering the development of affordable houses in each city.

In Indonesia, Saifullah (2016) showed that spatial planning policies were highly needed in the settlement development process. This was supported by the existence of a river boundary protection policy through a river border spatial planning policy as a protected area. However, due to the lack of a Spatial Detail Plan (Rencana Detail Tata Ruang, RDTR), a strongly layered bureaucracy in the process of implementing policies and ignorance of building regulations in river border areas became a major obstacle in the development of settlements. Furthermore, Nasriaty (2016) proved that the implementation of spatial planning policies had involved target groups and introduced procedure policies through socialization. However, the implementation of the Spatial Planning policy in North Mamuju Regency did not run optimally. This condition was supported by the existence of content policy in terms of inadequate resources, both in terms of quality and quantity.

Previous studies show variations in the implementation of land use policies for housing. This is also supported by the use of methods or modeling that are quite varied in each study. For this reason, the study aims at understanding the importance of a public policy perspective in the process of land use permit proposals for housing development.

\section{Methodology}

This study used a qualitative approach with a case study strategy (Yin, 2003). Semarang Regency has a very favorable geographical location, including: (1) being close to Semarang City as the Capital City of Central Java Province, (2) located on the golden triangle trajectory of trade in Central: Yogyakarta, Solo and Semarang, which is already famous for the slogan "Joglo Semar", (3) having easy access in the form of Semarang-Solo Toll Road which facilitates the transportation of goods from production centers to seaports and airports; and (4) having competitive advantages in the form of land availability and market prices for activities investment, although it is necessary to pay attention to the Semarang Regency Regional Regulation Number 6 of 2011 concerning the existing Spatial Planning (Regional Development Planning Agency, 2017). The types of data used in this study were primary and secondary data. The primary data was obtained from ten prospective informants who were investors or company representatives. The determination of ten informants was based on the consideration that they experienced and were involved in the process of discussing housing area development permits. Furthermore, the secondary data were obtained from the reports of the One Stop Investment Service and Integrated Services, Public Works Agency, and Regional Development Planning Research Agency of Semarang Regency. The collected data was then analyzed by descriptive analysis techniques. 


\section{Results and Discussion}

\subsection{Investment Development in Semarang Regency}

The interesting thing about Semarang Regency was that there was a significant investment development. This was evidenced from the development of the project and the value of investments invested in Semarang Regency from 2010 to 2018 which can be seen in Table 1 below.

Table 1. Development of Investment Values during 2010 until 2018

\begin{tabular}{|c|c|c|}
\hline \multirow{2}{*}{ Year } & Investment Per Year & Investment Value \\
\hline 2010 & 345.166 .000 .000 & 345.166 .000 .000 \\
\hline 2011 & 236.372 .000 .000 & 581.538 .000 .000 \\
\hline 2012 & 259.929 .000 .000 & 841.467 .000 .000 \\
\hline 2013 & 371.048 .000 .000 & 1.212 .515 .000 .000 \\
\hline 2014 & 1.735 .125 .000 .000 & 2.947 .640 .000 .000 \\
\hline 2015 & 404.612 .000 .000 & 3.352 .252 .000 .000 \\
\hline 2016 & 295.601 .000 .000 & 3.647 .853 .000 .000 \\
\hline 2017 & 1.003 .811 .167 .000 .000 & 1.007 .459 .020 .000 .000 \\
\hline 2018 & 1.776 .873 .386 .586 .000 & 2.784 .332 .406 .586 .000 \\
\hline
\end{tabular}

Table 1 shows the realization of the investment value in domestic investment (Penanaman Modal Dalam Negeri, PMDN) or foreign investment (Penanaman Modal Asing, PMA) in Semarang Regency in 2018 whose performance exceeds the target of IDR 1.776 .883 billion of the target set at IDR 396,69 billion or 447.92\%. The achievement of investment value looks quite large compared to the achievement of the total investment value in 2017 of IDR 1.003.811 billion. This indicates that there is an increase in the percentage of the total investment value of $77.01 \%$.

\subsection{Space Utilization Through a Land Consolidation Program}

The use of space as a housing location of Mr. MR was located in Nyatnyono Village, West Ungaran District, Semarang Regency covering an area of $\pm 6.643 \mathrm{~m}^{2}$. Initially, this activity plan did not get permit from the government to carry out the housing construction. This is in line with what was stated by Mr. MR as the permit applicant:

"I plan to develop residentials through Land Consolidation activities in Nyatnyono Village, which consists of two locations covering $\pm 3.957 \mathrm{~m}^{2}$ and $\pm 2.686 \mathrm{~m}^{2}$. According to the information I got from the related office, it turns out that the location is included in the plantation planning area. Actually, this location is directly adjacent to the location of previous land consolidation activities. Later, this is probably going to get the attention of the Semarang Regency government." 
From Mr. MR's description, it is illustrated that this housing activity did not get permit for its construction because it was not in accordance with the spatial regulations in Semarang Regency, where the location was not in the allocation of settlements but in the plantation planning area. The following Figure 2 is the location of the spatial utilization plan.

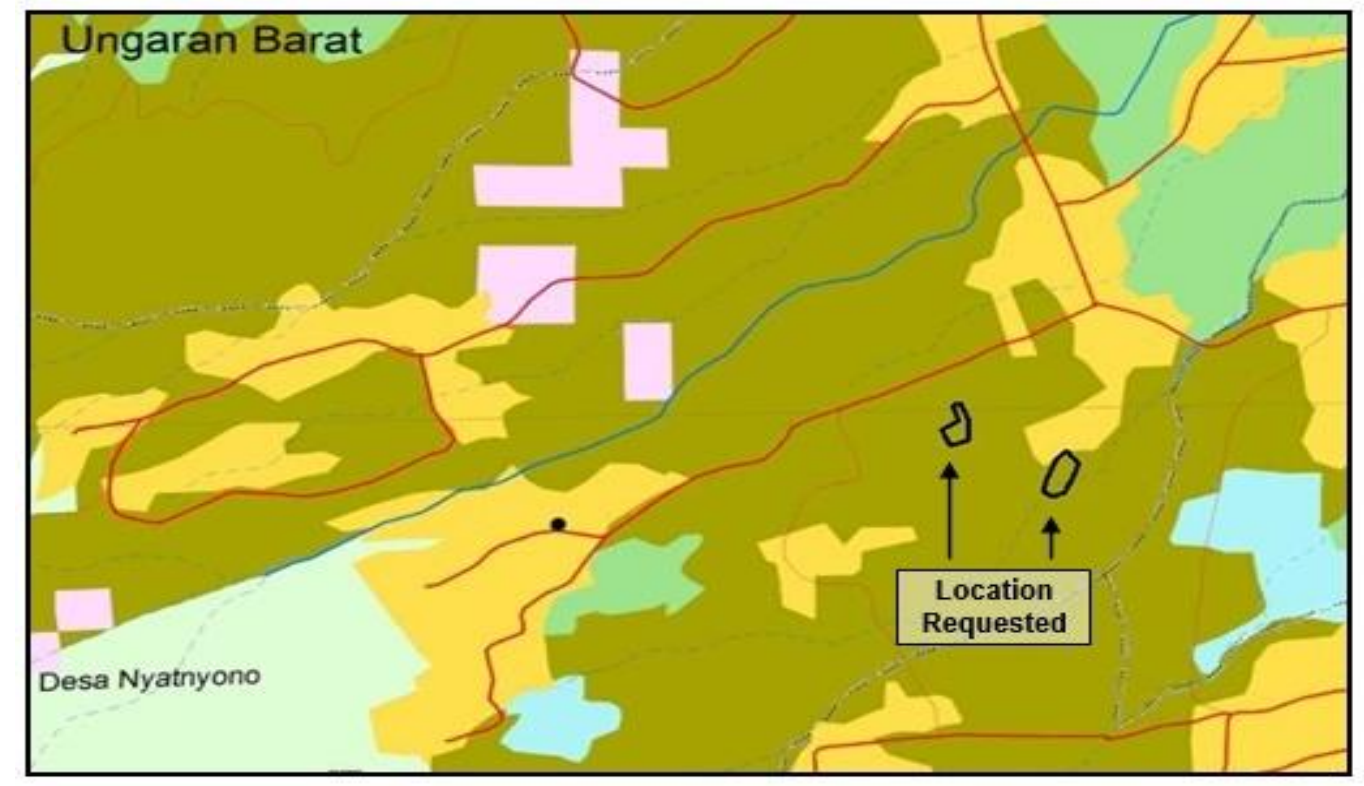

Fig. 2. Spatial Map of the Housing Plan Location Through A Land Consolidation Program

Note: Source: Public Works Agency (2018)

Dark Green: plantation area

Light Green: crop farming area

Yellow: rural settlement area

Orange: urban residential area

In terms of public policy, the Semarang Regency government decided to provide recommendations for the proposal with three considerations: (1) based on article 63 letter a. of Regional Regulation Number 6 Year 2011 which regulates the general provisions of zoning regulations for plantation Planning areas, it is stated that the use of space for settlements of local communities with low density is allowed on land with slopes of less than 25\% (twenty five per hundred) and on an expanse of lands integrated with existing settlements; (2) the location has been integrated with the location of the previous land consolidation activities and the planning of rural settlements; and (3) the housing plan is a land consolidation activity for the local community, with a low density (large plot area) and meeting the needs of public facilities. Cazacova et al. (2010), Musa et al. (2015) and Cesarski (2017) proved that the development of housing areas needed to pay attention to social and spatial aspects. Public policies taken by the relevant government had considered aspects of the strengths and weaknesses of developing residential areas (Davy, 2014; Holmes, 2013; McCord et al., 2014). The main objective was to utilize the land optimally, balanced and sustainably (Cazacova et al., 2010; Davy, 2014; Holmes, 2013; McCord et al., 2014). This was intended to get a win-win solution for meeting community needs and sustainable development (Davy, 2014; Dye, 2002; McCord et al., 2014; Nasriaty, 2016). In Semarang Regency, the land consolidation policies and activities were carried out by the National Land Agency which aimed to accelerate the land registration process (Gerber \& Hartmann, 2017; Holmes, 2013; Janssen-Jansen \& Lloyd, 2012). However, several cases often clashed with spatial provisions. This indicated that the land consolidation was still an important issue that needed to be resolved by the government wisely. 


\subsection{Space Utilization in Wide \& River Border Area}

The use of space for housing development activities phase II was proposed by KSP Ltd, covering an area of \pm $70,000 \mathrm{~m}^{2}$, an expanse of land located in the area of Sidomulyo and Kalirejo Subdistrict, East Ungaran District, Semarang Regency. This location blended with the phase I housing that had been previously issued. Actually, the proposed location was in accordance with the spatial planning included in the urban settlement area. However, the Semarang Regency government thought that it was necessary to reconsider the submission of its licensing proposal in order to meet the environmental, social and economic aspects. This was confirmed by Mr. K as the manager of the company.

"Our location is planned for the development of phase I housing that is already underway, and all of it is included in the planning of urban settlements, so that it is actually in accordance with spatial regulations, although indeed, the existing conditions show that they are rice fields and limited by rivers. In addition, we still have to work on the phase I permit for housing development related to the prevention of flooding or overflow of rivers around the site, as well as the social approach of the community. The $7 \mathrm{Ha}$ area could be the first and biggest land for filing a housing permit in Semarang Regency, so it needs some technical and non-technical considerations".

According to Mr. K, it is illustrated that this housing expansion activity needed further study and consideration because the existing conditions of the location were rice fields and technical engineering was needed to prevent flooding, not only in accordance with the existing spatial allocation. The following is the location of the space utilization plan that can be seen in Figure 3.

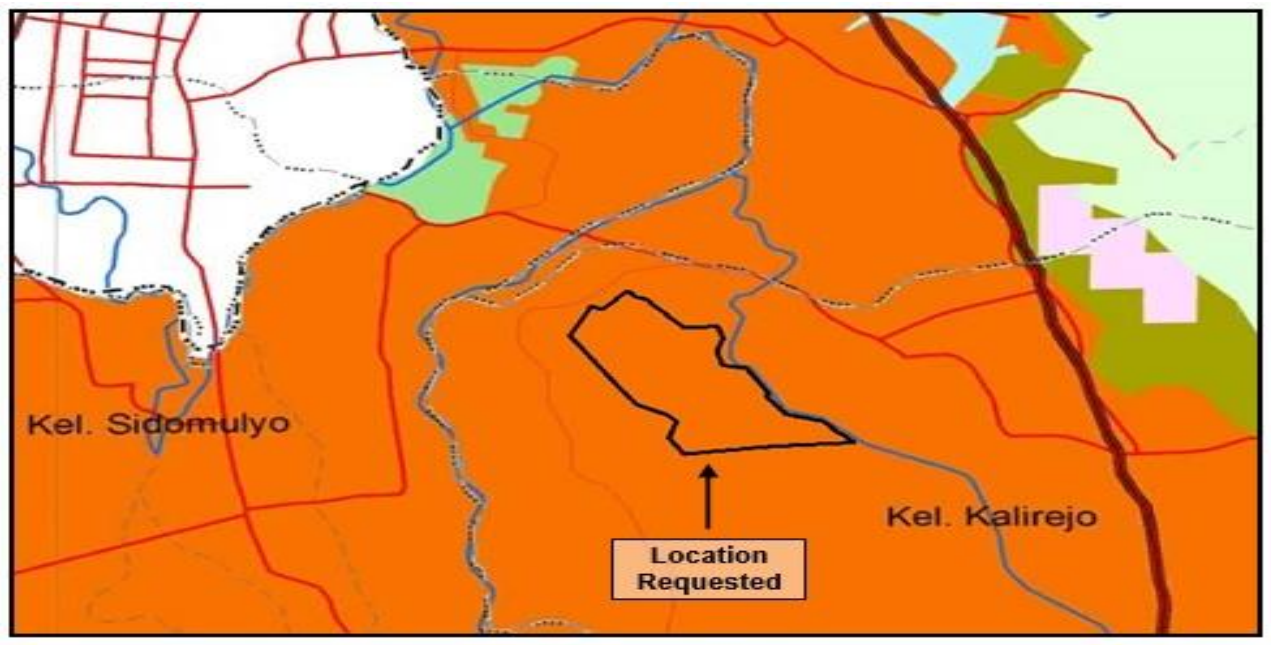

Fig. 3. Spatial Map Housing Plan Location with Wide and River Border Area Source: Public Works Agency (2018)

According to a study by members of the Semarang Regency spatial planning coordination body, the recommendation for a phase II housing location permit could be given with the following considerations: (1) the location should be located in the area of urban settlement planning; (2) based on the provisions of Article 69 letter a. of Regional Regulation Number 6 of 2011, which regulates the general provisions of zoning regulations for urban settlement planning areas that urban and rural residential areas must be safe, comfortable and productive, and supported by housing facilities and infrastructure; and (3) phase housing II must fulfill the obligation to build 


\section{INSIGHTS INTO REGIONAL DEVELOPMENT}

ISSN 2669-0195 (online) http://jssidoi.org/jesi/

2019 Volume 1 Number 4 (December)

http://doi.org/10.9770/IRD.2019.1.4(1)

a retention pond and river channel arrangement as a flood prevention effort and to fulfill the needs of public facilities. Cazacova et al. (2010) and Antczak (2017) proved that urban areas offered important opportunities for economic development and expansion of access to basic services such as health, education and housing. However, there were still problems faced such as uncontrolled urban expansion, poor management and a lack of spatial urban planning systems (Castañeda \& Guerrero, 2018; Ogrodowczyk, 2015; Saifullah, 2016; Seo \& Kwon, 2017). In Semarang Regency, river boundary protection policies were regulated through river border spatial planning policies as protected areas. However, due to the lack of a Spatial Detail Plan (Rencana Detail Tata Ruang, RDTR), a highly layered bureaucracy in the process of implementing policies and ignorance of building regulations in river border areas became a major obstacle in the development of settlements. Thus, public policy must be designed to eliminate or reduce the inconvenience and displeasure of individuals and community groups (Dye, 2002).

\subsection{Space Utilization in Vacant Spatial Planning Area}

The use of space as a housing location was proposed by Mr. QA, located in Gedangan Village, Tuntang District, Semarang Regency, covering an area of $\pm 2.660 \mathrm{~m}^{2}$. Initially, this housing development plan did not get a permit from the government, because based on the space pattern of Regional Regulation number 6 in 2011, the location was in the vacant allocation area. This is in line with what was stated by Mr. QA as the permit applicant.

"From the information on the spatial plan obtained, our location is included in the vacant planning area, so the Semarang Regency government does not give permit for this housing establishment. However, our location is close to the border between Semarang Regency and Salatiga City. The existing condition of the location in question is located in the dominant area with plantations in the area of Semarang Regency and predominantly with settlements in the Salatiga City area".

From the explanation above, Mr. QA illustrated that this housing development plan did not get permit to operate because it clashed with spatial regulations in Semarang Regency (included in the vacant allocation area). Figure 4 presents the location of the space utilization plan.

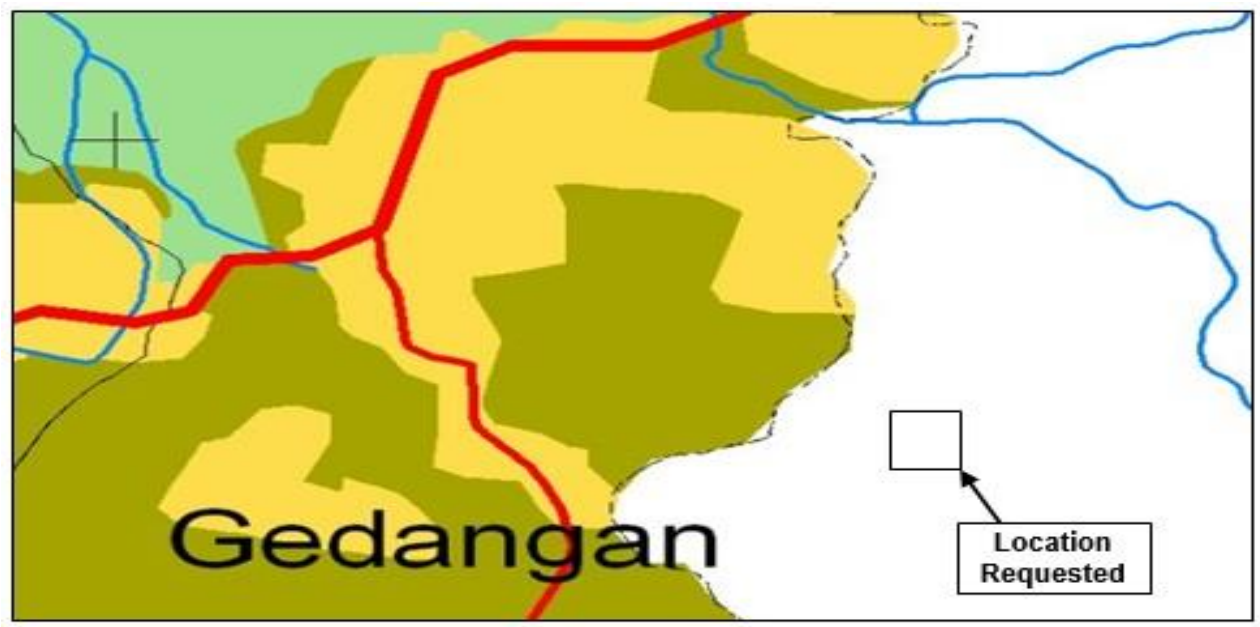

Fig. 4. Spatial Map of Housing Plan Location in Vacant Spatial Planning Area Source: Public Works Agency (2018)

Based on the consideration of members of the Semarang Regency spatial planning coordinating body, a housing development could be given recommendations with the following considerations: (1) the closest allotment area to 


\section{INSIGHTS INTO REGIONAL DEVELOPMENT}

ISSN 2669-0195 (online) http://jssidoi.org/jesi/

2019 Volume 1 Number 4 (December)

http://doi.org/10.9770/IRD.2019.1.4(1)

the intended location is the plantation planning area and in accordance with Semarang Regency Regional Regulation Number 6 of 2011; (2) to pay attention to the Semarang Regency Regulation Number 6 of 2011 article 63 which regulates the general provisions of zoning regulations for plantation planning areas, stating that: (a) space utilization for low density local community settlements is allowed on land with slopes of less than $25 \%$ and on an expanse of land that blends with existing settlements; (b) construction of supporting facilities and infrastructure for plantations including agritourism is only permitted on land with slopes of less than 25\%; (c) plantation cultivation is directed at productive types of annual plants by considering environmental conservation aspects; (d) the provisions for the prohibition of the conversion of plantation land into non-agricultural cultivated land must refer to legislation; (3) the permit for utilization of space is only for residential homes, with the following requirements: (a) settlement plans integrated with existing settlements and no physical barriers (fences) can only be used for individual purposes or built naturally, not built by the developer or not real estate, or not in the form of clusters; (b) intended for people who live around the location in one District; (c) the Building Base Coefficient (Koefisien Dasar Bangunan, KDB) is permitted at a maximum of $30 \%$ of the land area; (d) does not change or maintain the dominance of the function of the area as an plantation planning area; (e) does not cause negative environmental and social impacts in the future and (4) the implementation of spatial utilization must pay attention to the Land Technical Considerations (Pertimbangan Teknis Pertanahan, PTP) of the Semarang Regency Land Office and the applicable regulations regarding building and environment. Cesarski (2017); Cooke and Moon (2015); McCord et al. (2014); Davy (2014); Holmes (2013) and Nasriaty (2016) proved that housing and settlement policies were one of the solutions addressing ecological and conservation issues. According to Dye (2002), public policy was able to help housing policy makers, consultants, developers, contractors, and other stakeholders in housing program planning and development. In Semarang Regency, the arrangement of building area was regulated through regional regulations. However, the supervision of the building area built by the community had not been carried out optimally. This could cause natural water infiltration to be hampered, so that the efforts intended for water infiltration would experience a few obstacles.

\subsection{Space Utilization for Communities Affected by Railroad Project}

There was a space utilization planned for residentials for residents affected by the Tuntang - Kedungjati railroad reactivation project. The area proposed by Mr. AM was located in Bringin Village, Bringin District, Semarang Regency covering an area of $\pm 13.100 \mathrm{~m}^{2}$. Initially, the plan to establish this housing did not get permit from the government, because the location was in the area of the water infiltration planning area. This is in line with what was stated by Mr. AM as the permit applicant.

"We plan to help residents whose land is affected by the railroad reactivation project, so that they can immediately get a replacement for a residence, not far from the previous location. Unfortunately, according to the information from the related agency, it turns out that the location is in a water infiltration area. We ask for a consideration by the Semarang Regency Government so that our proposal can be approved".

According to Mr. AM, it was illustrated that the planned housing activity did not get a permit because the location was not in accordance with the spatial planning. The following is the location of space utilization which can be seen in Figure 5. 


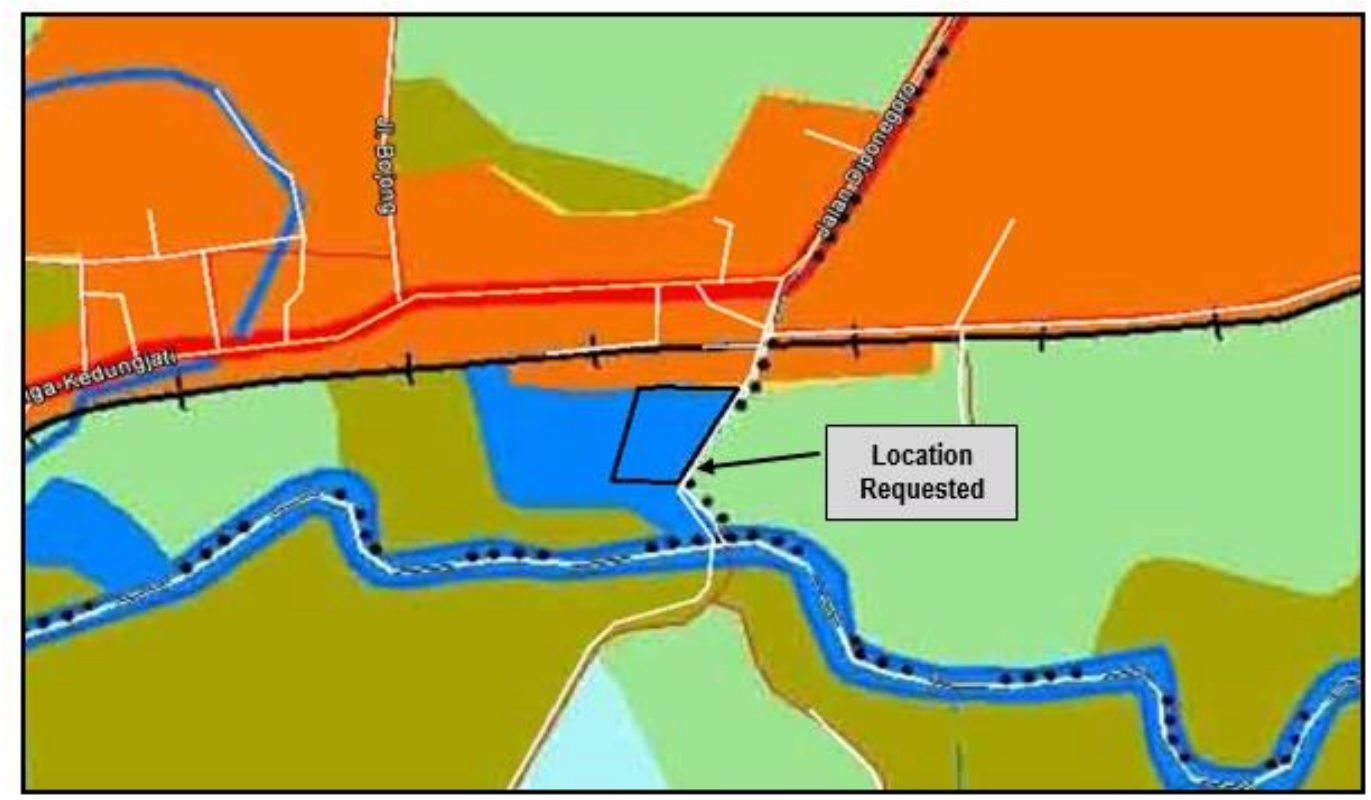

Fig. 5. Spatial Map of Housing Plan Location for Communities Affected in the Railroad Project Source: Public Works Agency (2018)

Based on the considerations of members of the Semarang Regency spatial planning coordinating body, plans for housing activities could be given recommendations with the following considerations: (1) the applicant is a railway-reactivation-project-affected person (Warga Terkena Proyek, WTP); (2) the certificates owned have the status of Property Rights (Hak Milik); (3) plotting of water infiltration in the spatial pattern of Regional Regulation number 6 of 2011 in the location in question is irrational because it is adjacent to the river; (4) space utilization is only for residential houses as needed and (5) maximum land area that can be built is only $500 \mathrm{~m}^{2}$. Seo and Kwon (2017), Cesarski (2017), Ogrodowczyk (2015), and Davy (2014) proved that housing shortages were a serious problem in urban areas. The government also encouraged partnerships with communities and the private sector to provide various types of housing (Musa et al., 2015; Seo \& Kwon, 2017). This phenomenon showed that the government must be wise in considering the development of affordable housing in each city. Public policy was not just a decision that produced separate activities. However, it was seen as a long series of interconnected activities. It was not solely related to what the government could or could not do, but it involved a number of activities related to the public interest (Dye, 2002). Furthermore, the determined public policies were influenced by socio-economic conditions such as level of education, community income, poverty, quality of life, and competitiveness (Antczak, 2017; Cazacova et al., 2010; Cesarski, 2017; Musa et al., 2015). In Semarang Regency, the interests of the wider community remained an important consideration in making land use policy for housing. The process of implementing spatial planning policies was carried out through socialization and approaches to the community (Nasriaty, 2016).

\subsection{Space Utilization in Spatial Planning Area of Crop Farming}

The use of space for the housing plan was proposed by Mrs. SB, located in the Genuk Village, West Ungaran District, Semarang Regency, covering an area of $\pm 1.594 \mathrm{~m}^{2}$. Initially, this housing development plan did not get permit from the government. Below is a statement by Mrs. SB as a housing developer.

"The location we are proposing is, indeed, in the area of crop farming allocation. However, based on the Regional Regulation I read for the general provisions of zonation of crop farming 
areas, it was stated that the use of space for local residents with low density is allowed in irrigated rice fields on an expanse of land integrated with existing settlements. In line with that, our location is the rice fields that are not irrigated and are an expanse of land integrated with 2 (two) locations with issued Permits for Changing Agricultural Land Use to Non-Agricultural (drying permits), which are currently being used for housing that I am developing. Therefore, considering some of these things, we humbly ask the government to provide a policy, so that our permits may be approved".

According to Mrs. SB, it was illustrated that the planned housing activities did not get permit to operate because the location was not in accordance with the spatial planning, which should be located in the area of settlement allocation, but the location turned out to be located in the allocation area for crop farming. The following Figure 6 is the location of space utilization.

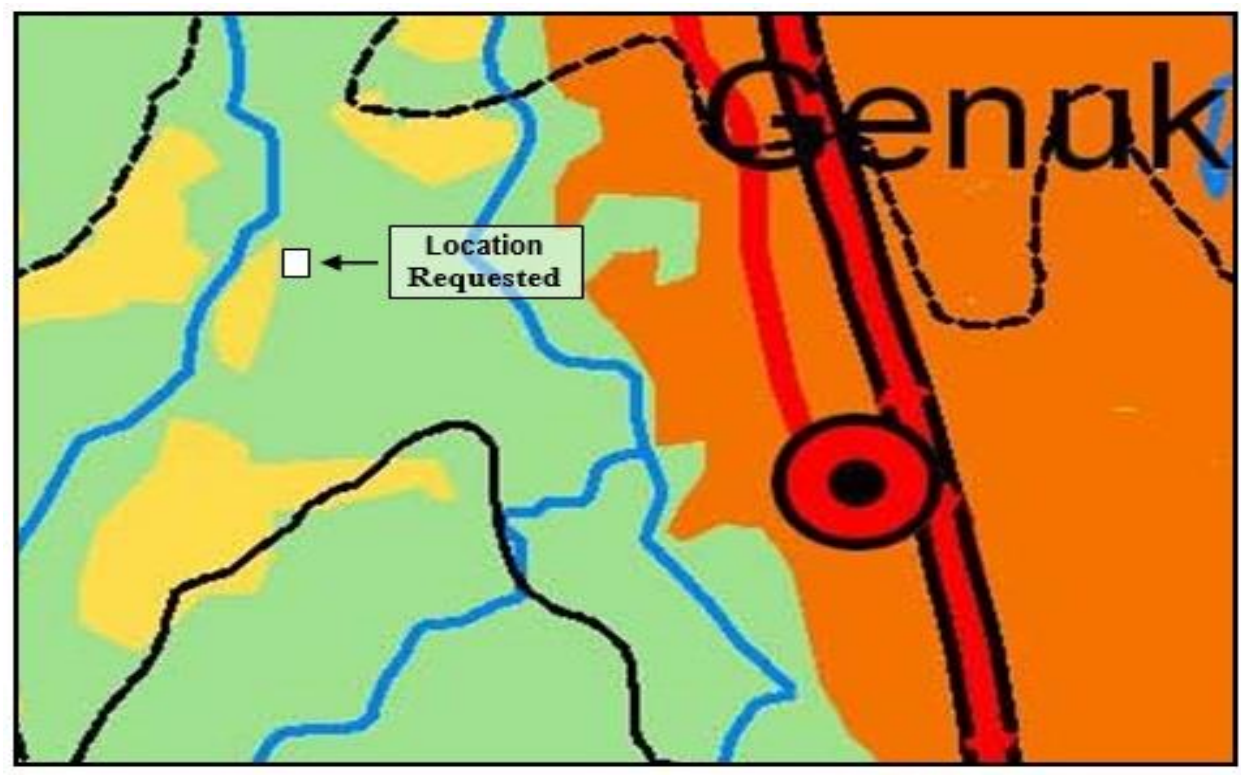

Fig. 6. Spatial Map of Housing Plan Location in Spatial Planning of Crop Farming Source: Public Works Agency (2018)

Based on the study of members of the Semarang Regency spatial planning coordinating body, it was concluded that the location was not recommended for housing, but only for public facilities and green open space (Ruang Terbuka Hijau, RTH) of housing that had been previously built. This is based on several considerations as follows: (1) for spatial control purpose and preventing the growth of settlements continuously with the reason attached to existing settlements which results in reduced crop farming areas; (2) to pay attention to Article 5 paragraph (2) letter b. of Semarang Regency Regulation Number 6 of 2011 which states that one of the maintenance strategies and the realization of the sustainability of functions and carrying capacity of the environment is by maintaining the function and water infiltration area in all regions and (3) to pay attention to Article 25 of Semarang Regency Regulation Number 6 of 2011 states that West Ungaran District is included in Water Infiltration Areas. Antczak (2017), Cooke and Moon (2015) and McCord et al. (2014) showed that space utilization policies needed to pay attention to urban greening aspects such as parks, streets, green areas in housing, tombs and forests. This policy was believed to be able to support conservation efforts in residential areas. The policy of urban green open space had a positive and significant impact on the selling prices of properties such as housing and apartments (McCord et al., 2014). Therefore, the land use planning needed to involve all stakeholders (McCord et al., 2014; Musa et al., 2015; Seo \& Kwon, 2017). Thus, public policy involved a number of activities 
involving various parties to produce decisions related to the public interest (Dye, 2002). In Semarang Regency, the land use activities had been regulated provided that there was an obligation to provide green open space of at least $40 \%$ of the land area. The determination of these rules was written in the regional regulations which during the preparation had involved various stakeholders.

\subsection{Space Utilization with A Housing Certificate Status}

Space utilization for housing development plans proposed by HBS Ltd was located in Leyangan Village, East Ungaran District, Semarang Regency with an area of $\pm 9.910 \mathrm{~m}^{2}$. Initially, the location request for this housing did not get permit from the government. This is in line with what was stated by Mr. $\mathrm{H}$ as a housing developer.

"The location of the housing plan we proposed is partly in the area of plantation planning and partly in the allocation area of crop farming, and it is necessary to get a consideration from the Semarang Regency government. Reading the Regional Regulation number 6 of 2011 concerning zoning provisions for allotment areas for crop farming and plantation planning areas, as far as I know, the use of space for local settlements with low density is permitted. In addition, the certificate of land I have has a Property Right status and housing status of I D and II D".

From the explanation above, Mr. H illustrated that the proposal for the location of the housing did not get a permit because the location was not in accordance with the spatial planning. The following Figure 7 is the location of space utilization.

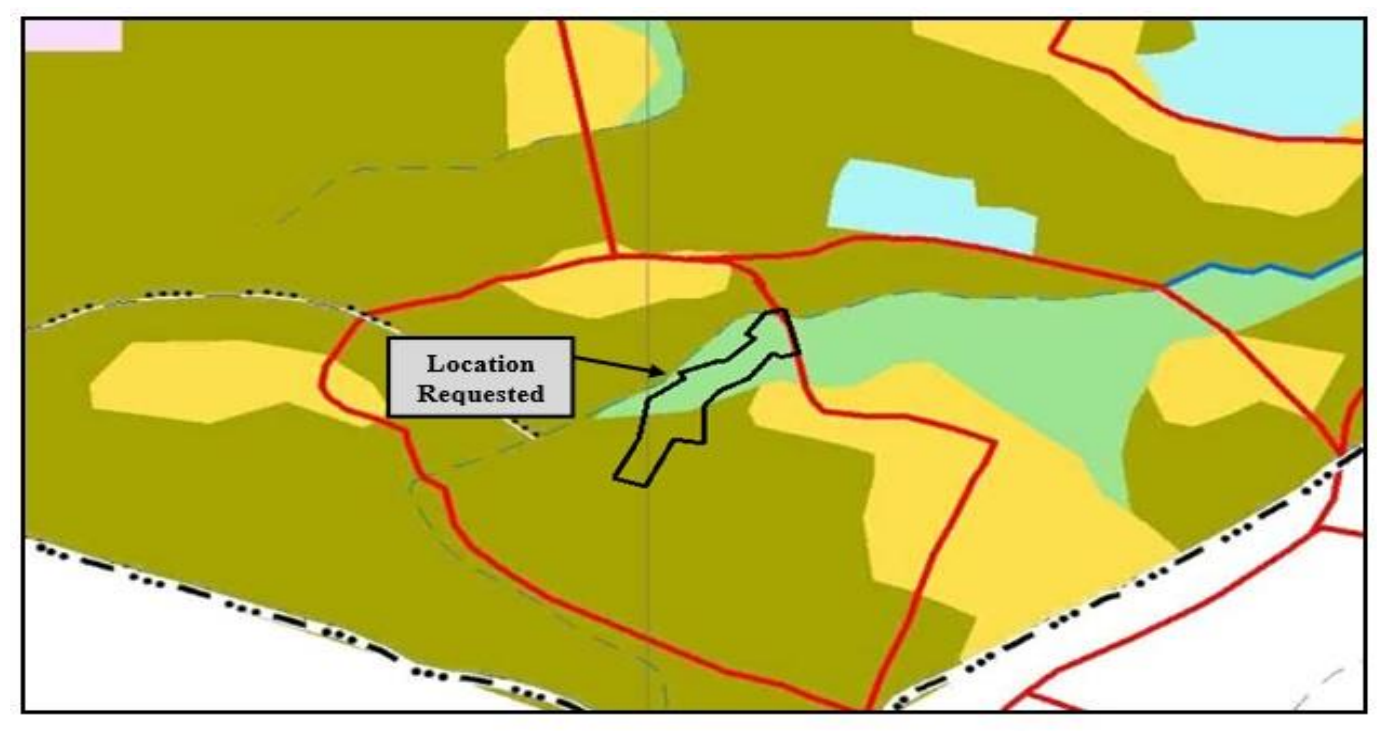

Fig. 7. Spatial Map of Housing Plan Location on Plantation Allocation Areas with Housing Certificate Status Source: Public Works Agency (2018)

Based on a study of members of the Semarang Regency spatial planning coordinating body, the proposal could be given recommendations for housing supported with supporting facilities and infrastructure, based on several considerations as follows: (1) the Zoning Provisions for plantation planning areas in Article 63 of Regional Regulation Number 6 of 2011 concerning the SPATIAL PLANS of Semarang Regency in 2011-2031 states that permissible activities are the use of space for local residents with low density and the construction of facilities and infrastructure supporting plantations including agritourism is only allowed on land with slopes of less than 25\% 


\section{INSIGHTS INTO REGIONAL DEVELOPMENT}

ISSN 2669-0195 (online) http://jssidoi.org/jesi/

2019 Volume 1 Number 4 (December)

http://doi.org/10.9770/IRD.2019.1.4(1)

and on an expanse of land integrated with existing settlements; (2) the Zoning Provisions for allotment of crops farming in Article 61 of Regional Regulation Number 6 of 2011 concerning the Spatial Plans of Semarang Regency in 2011-2031 states that permissible activities are the use of space for local residents with low density and the construction of supporting facilities and infrastructure for agriculture including agritourism are only permitted in irrigated rice fields on an expanse of land integrated with the existing settlements; (3) certificates owned consist of 3 certificates with class II D and 1 certificate with class I D; (4) according to the information from the Semarang Regency Land Office, certificates with class I D and II D can be used for housing; (5) restrictions on activities are only at the intended location in accordance with HM (Property Right) certificate Number 1968, 1812, 1850 and 1851 covering an area of $\pm 9.910 \mathrm{~m}^{2}$ without disrupting farming and plantation activities and (6) to pay attention to the applicable regulations regarding building and environment. Gerber and Hartmann (2017); Holmes (2013) and Janssen-Jansen and Lloyd (2012) proved that the land use policies for housing development could guarantee property rights of each community. Furthermore, this policy was also able to control land allocation for housing development projects (Davy, 2014; Gerber \& Hartmann, 2017; Holmes, 2013). In fact, issuing land certificates to build houses often experienced problems with environmental management (Holmes, 2013; Janssen-Jansen \& Lloyd, 2012). However, the land use policy was such an alternative to reconcile the issue. In Semarang Regency, the regional regulations governing spatial and regional plans had not been based on field maps and land certificates, so that the state documents, such as the land certificates, were an important consideration in the process of permitting space utilization. Thus, public policy was a number of actions by a person, group or government that provided obstacles as well as opportunities to achieve goals and objectives (Dye, 2002).

\subsection{Space Utilization in Plantation Planning Area}

Space utilization for housing development plans proposed by Mr. SHD was located in Kalongan Village, East Ungaran District and it was an area of $7.139 \mathrm{~m}^{2}$ (in a property right status). This location was in a plantation planning area. Initially, the proposal for housing construction did not get permit from the government. Mr. SHD as a housing developer stated that:

"According to the current regional regulations, our housing development plans are in the plantation planning area. Therefore, there needs to be a study and consideration from the local government. Even though we previously had a Property Right certificate, we really hope that the proposal can be approved".

Based on the explanation, Mr. SHD illustrated that the proposal for the planned housing development did not get a permit because the location was not in accordance with the spatial planning. The following Figure 8 is the location of space utilization. 


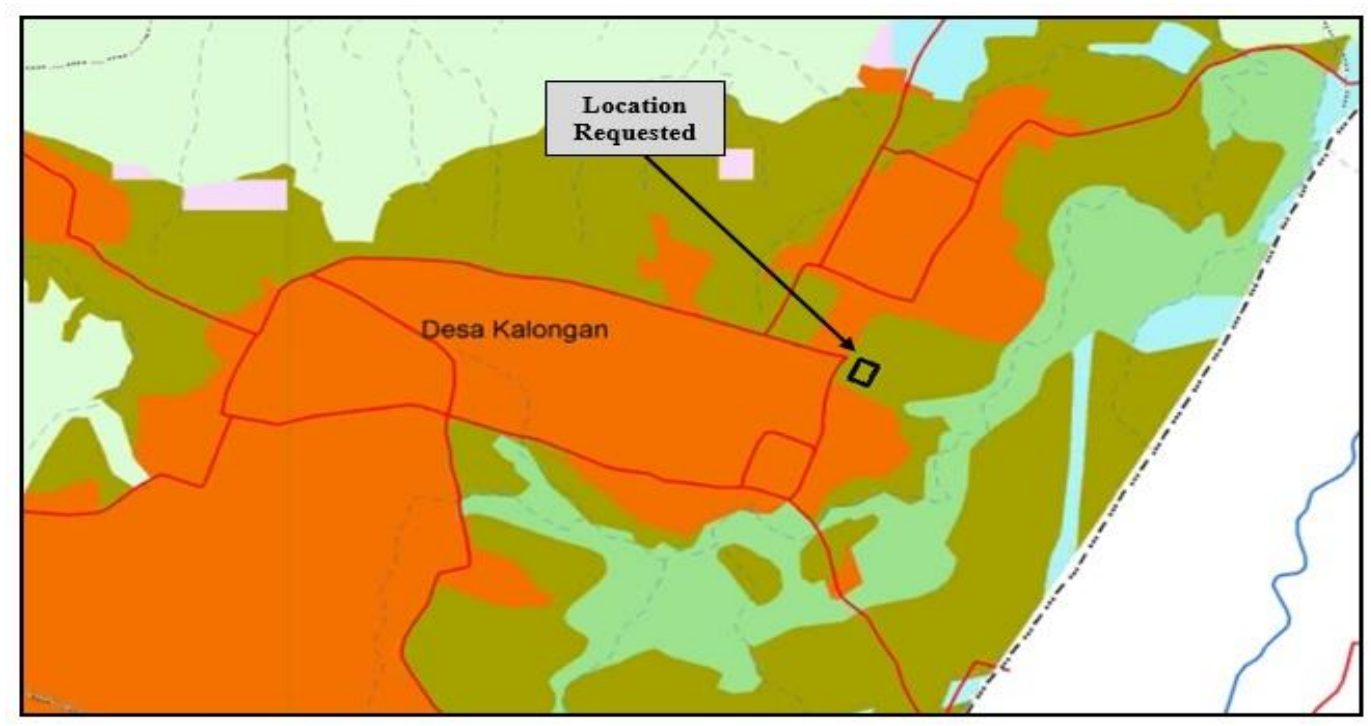

Fig. 8. Spatial Map of Housing Plan Location in Plantation Planning Area Source: Public Works Agency (2018)

The same thing was also experienced by Mrs. DW whose location was in Kalongan Village, East Ungaran District and it was an area of $12.048 \mathrm{~m}^{2}$ (in a Property Right status). This location was in the plantation planning area. Initially, the proposal for housing construction did not get permit from the government. This is in line with what was stated by Mrs. DW as a housing developer.

"Based on the information on the spatial plan we proposed, the plan for our housing location is in the plantation planning area. The Semarang District Government may need to review and consider a number of things. I have great hope for the fulfillment of this request for we also have the Property Right certificates of class II D".

Based on the explanation of Mrs. DW, it was illustrated that the proposal for the planned housing development did not get a permit because the location was not in accordance with the spatial planning. Figure 9 presents the location of space utilization. 


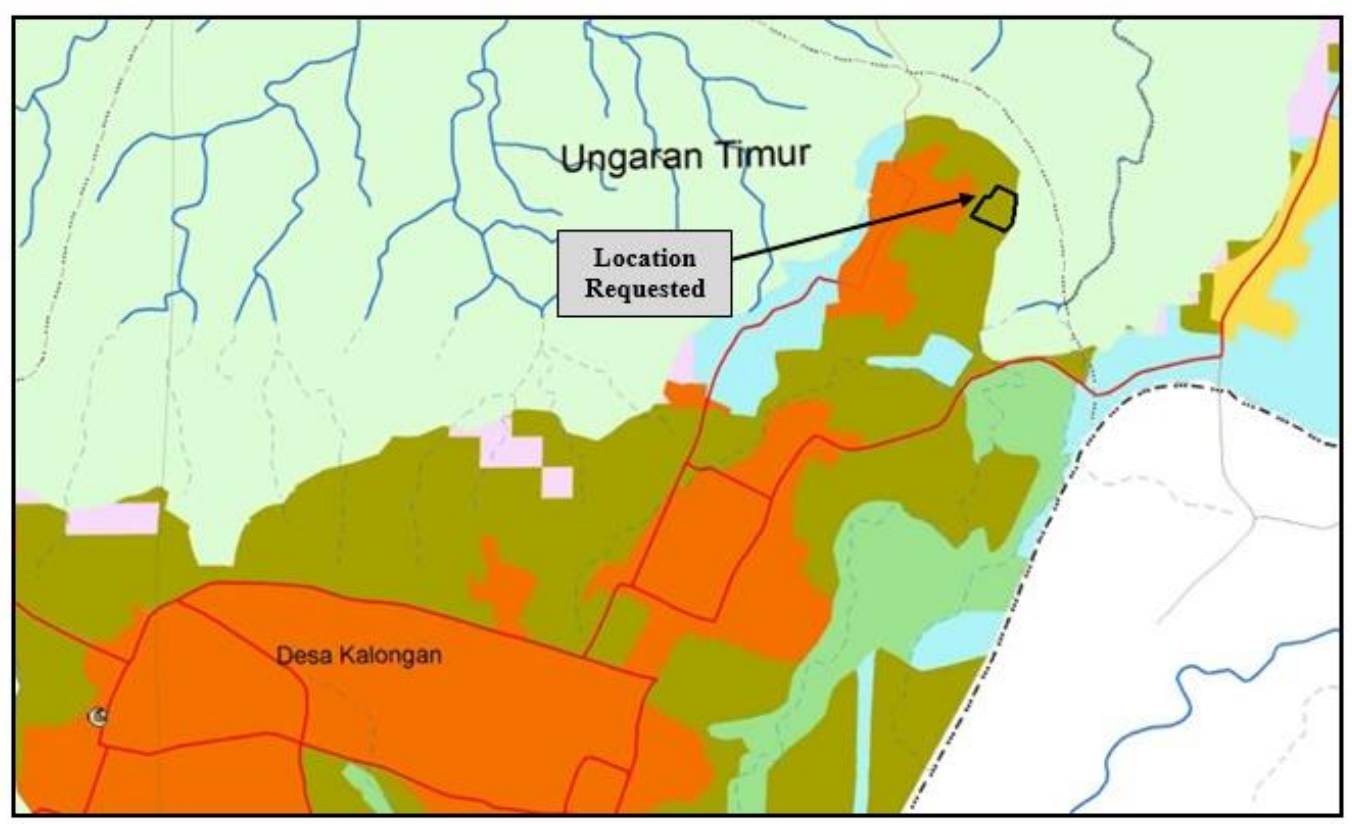

Fig. 9. Spatial Map of Housing Plan Location in Plantation Planning Area Source: Public Works Agency (2018)

Likewise, there was also a request for location permit from Mr. HM which was located in Candirejo Village, Tuntang Sub-district with a land area of $3.555 \mathrm{~m}^{2}$ (in a property right status). This location was in the area of plantation planning $( \pm 85 \%)$ and rural settlement areas $( \pm 15 \%)$. Initially, the proposal for housing construction did not get permit from the government. The following is a statement by Mr. HM as a housing developer.

"According to the current regional regulations, our housing development plan is located on a land which is mostly located in the area of plantation planning area and its small portion is in the area of the rural settlement. Normatively, for housing activities, those that are in accordance with the provisions of spatial planning are probably only those that are located in the planning area of rural settlements. Therefore, we hope that there will be studies and considerations from the regional government so that our proposal can be fully approved".

From Mr. HM's description, it was illustrated that the proposal for the housing development plan did not get a permit because the location was mostly not in accordance with the spatial planning. The following Figure 10 is the location of space utilization. 


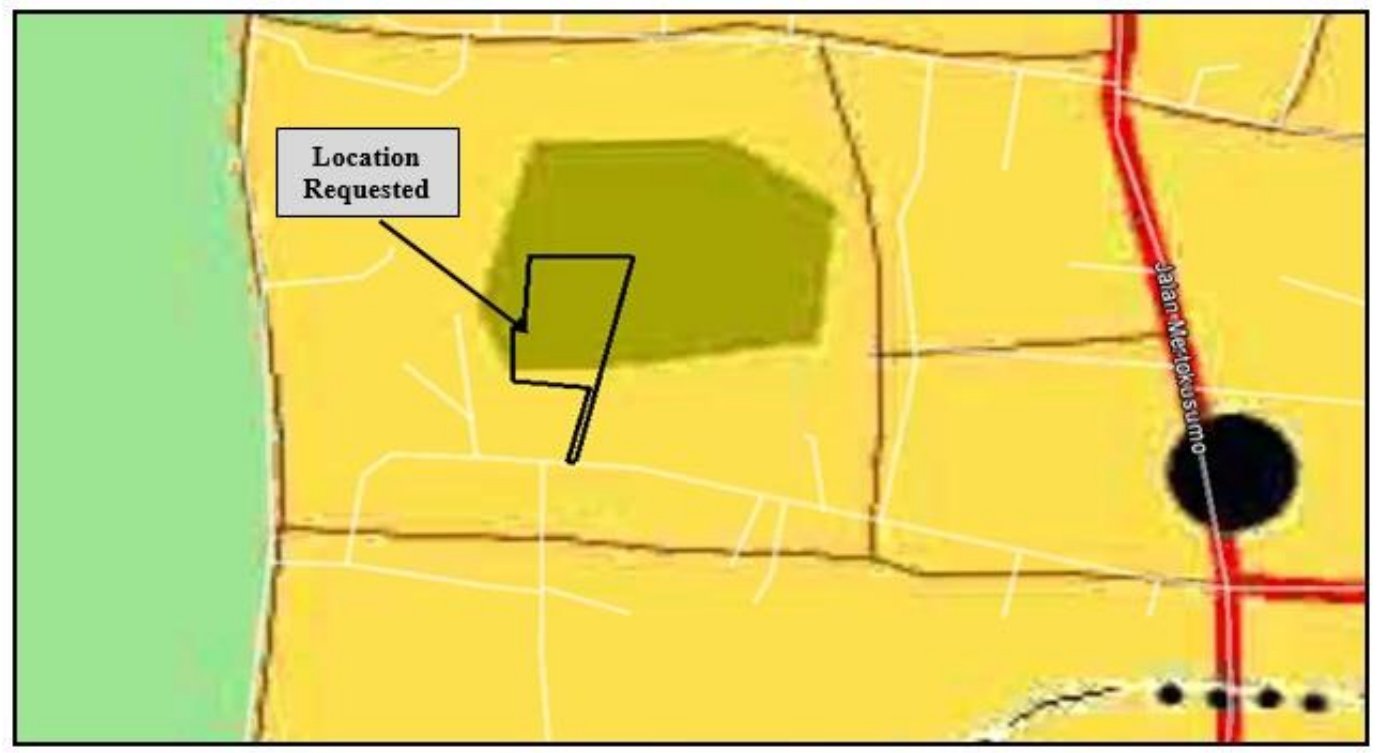

Fig. 10. Spatial Map of Housing Plan Location in the Allocation Area of Plantation and Settlement Source: Public Works Agency (2018)

According to the consideration of members of the Semarang Regency spatial planning coordinating body, the proposal for a location for housing could be given recommendations by considering that: (1) land status should be in the form of class II D (housing) of Property Right; (2) physical conditions should be in the form of plantations adjacent to existing settlements with land slopes of $8-25 \%$ and15-25\%; (3) space utilization for housing is supported with facilities and infrastructure to support the development of urban areas in the East Ungaran District; (4) restrictions on activities are only at the intended location and in accordance with the Property Rights certificate by not interfering with the surrounding plantation activities and (5) to pay attention to the applicable regulations regarding the building and environment. Slightly different from Mr. SHD and Mrs. DW, the proposal for location for Mr. HM's housing could be given a recommendation by considering that the existing conditions should be in the form of plantation and integrated with existing settlements, with a slope of $0-8 \%$. Castañeda and Guerrero (2018), Antczak (2017) and Cazacova et al. (2010) proved that public policy was designed to accelerate economic development and expand access to basic services for the community. However, the implementation of public policies often faced obstacles such as uncontrolled urban expansion, poor management, lack of spatial urban planning systems, and lack of guarantees of community property rights (Antczak, 2017; Gerber \& Hartmann, 2017; Holmes, 2013; Janssen- Jansen \& Lloyd, 2012). Not all public problems could be a policy problem, only those which could move many people to come to think about and find solutions to the problems they faced. To make public policy to be able to solve public problems, the public problems must be transformed into policy issues. Thus, agenda setting activities were the main requirement for making public problems a policy problem (Dye, 2002). In Semarang Regency, the policy of space utilization for settlements was directed to the eastern region (East Ungaran) to avoid water infiltration areas, most of which were in the western region (West Ungaran). This had been scheduled or stated in the Semarang district midterm development plan of 2016 until 2021.

\subsection{Space Utilization in The Vacant Spatial Planning Area Adjacent to The Border of Other City Administration Area}

Location proposal for housing activity plan by Mr. JM was located in Candirejo Village, Tuntang District with a land area of $2.313 \mathrm{~m}^{2}$ (in a Property Right status and a letter C village). This location was in the vacant allotment area, so that consideration was needed by the regional government whether the process could be continued or not. 
INSIGHTS INTO REGIONAL DEVELOPMENT

ISSN 2669-0195 (online) http://jssidoi.org/jesi/

2019 Volume 1 Number 4 (December)

http://doi.org/10.9770/IRD.2019.1.4(1)

Initially, the proposal for housing construction did not get permit from the government. Below is a statement by Mr. JM as a housing developer.

"We obtained information from the relevant agencies that the planned location of the housing that I will build is in the vacant allotment area based on the map of the spatial pattern in the current Regional Regulation. The location is, indeed, adjacent to the administrative area of Salatiga city. Then, I try to get consideration from the local government so that our proposal can be approved".

According to Mr. JM, it was illustrated that the proposal for the housing development plan did not get a permit because it was not in accordance with the spatial regulation, which was included in the vacant allotment area. The following Figure 11 is the space utilization location.

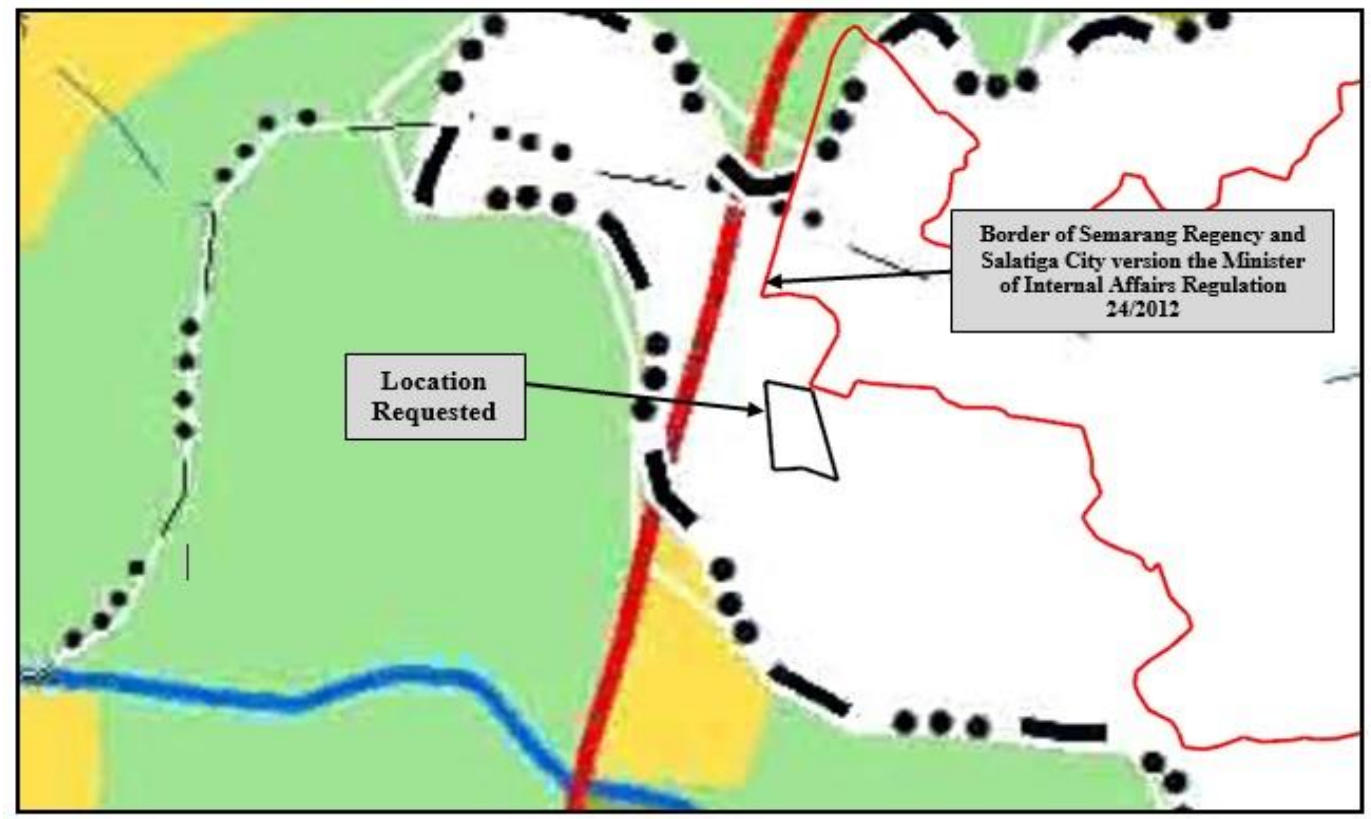

Fig. 11. Spatial Map of Housing Plan Location in the Vacant Spatial Planning Area Close to the Borders of Other City Administration Area Source: Public Works Agency (2018)

According to a review of members of the Semarang Regency spatial planning coordinating body, the proposals could be given recommendations by considering that: (1) it is in accordance with the delineation of territorial boundaries in Minister of Internal Affairs Regulation (Permendagri) Number 24 of 2012 concerning the Administrative Territory Boundary between Salatiga City and Semarang Regency that the overall location of the request is in the administrative area of Semarang Regency; (2) the land is in a status of Property Rights and a C village (certificate from the Land Office of Semarang Regency) with an area of $2.313 \mathrm{~m}^{2}$; (3) the physical condition should be in the form of a yard integrated in a residential environment with a slope of $0-8 \%$; (4) the space utilization for housing is supported with supporting facilities and infrastructure for settlements; (5) restrictions on activities are only at the intended location and in accordance with the Property Rights and a $\mathrm{C}$ village covering an area of $\pm 2.313 \mathrm{~m}^{2}$ and (6) to pay attention to the applicable regulations regarding the building and environment. Cesarski (2017); Davy (2014) and Musa et al. (2015) proved that the political, economic and social dimensions influenced the success of public housing projects in developing countries. In other words, housing and settlement policies were able to facilitate the existing social, political, economic and ecological 


\section{INSIGHTS INTO REGIONAL DEVELOPMENT}

ISSN 2669-0195 (online) http://jssidoi.org/jesi/

2019 Volume 1 Number 4 (December)

http://doi.org/10.9770/IRD.2019.1.4(1)

relations (Janssen-Jansen \& Lloyd, 2012; Cesarski, 2017; Davy, 2014; Musa et al., 2015). Public policy should allow the government to do many things for all community groups. This means that the government could help with their interests and solve the problems they faced (Dye, 2002). If there were spatial issues related to the administration of other cities, the Semarang Regency government would coordinate with the Central Geospatial Information Agency. This indicated that coordination was very important in order to produce beneficial decisions.

\section{Conclusions}

Public policy should be made intentionally, because it aims to realize a certain goal. The same thing happened in Semarang Regency, where public policy was used to mediate spatial issues. There were ten proposals for land use permits which were initially not approved. However, the existence of public policy with certain conditions issued by the Semarang Regency government made the ten land use permit proposals approved by the government. Requests for land use permits were submitted by ten housing developers namely Mr. MR, Mr. K, Mr. QA, Mr. AM, Mrs. SB, Mr. H, Mr. SHD, Mrs. DW, Mr. HM, and Mr. JM. This study provide evidence from ten informants there are eight cases as follows space utilization through a land consolidation program, space utilization in a wide \& river border area, space utilization in vacant spatial planning area, space utilization for communities affected by railroad project, space utilization in spatial planning area of crop farming, space utilization with a housing certificate status, space utilization in plantation planning area, and space utilization in the vacant spatial planning area adjacent to the border of other city administration area. However, after being considered by the government in terms of public policy, the ten location permits were issued with certain conditions. Thus, it could be concluded that the public policy was essentially designed by the government to guarantee and fulfill the needs of the community in conducting investment activities such as housing developers.

Some of the limitations are the alleged emergence of transaction and negotiation costs, guarantees and settlement of transactions through the market economy. This is based on the assumption that the actors in the institution have a purpose or motive for self-interest while still working behind the government structure (Dye, 2002). In addition, the informants were only based on ten land use location permits that were initially not approved, but the existence of public policies made the ten location permits approved by the government. Future research should be directed at examining the Dye's theory in regulating national housing development. Therefore, further studies need to examine public policy and institutional economics related to spatial planning.

\section{References}

Antczak, E. (2017). Urban Greenery in the Greatest Polish Cities: Analysis of Spatial Concentration. International Journal of Urban and Civil Engineering, 11(5), 578-585. Retrieved from https://waset.org/Publication/urban-greenery-in-the-greatest-polish-cities-analysis-ofspatial-concentration/10006922

Castañeda, G., \& Guerrero, O. A. (2018). The Resilience of Public Policies in Economic Development. Complexity, $2018,1-15$. https://doi.org/10.1155/2018/9672849

Cazacova, L., Erdelhun, A., Saymanlier, A. M., Cazacova, N., \& Ulbar, U. (2010). Social and Spatial Aspects of Housing Development Affecting Urban Quality of Life - the Case of Famagusta. International Journal of Humanities and Social Sciences, 4(6), 1016-1029. Retrieved from https://waset.org/publications/8077/social-and-spatial-aspects-of-housing-development-affecting-urban-quality-of-life-thecase-of-famagusta

Central Bureau of Statistics. (2018). Kabupaten Semarang Dalam Angka. Semarang: Central Bureau of Statistics.

Cesarski, M. (2017). Habitation as a goal and subject of public policy sciences - the role of housing and settlement Abstract. Studia $z$ Polityki Publicznej, 1(13), 65-86. Retrieved from http://hdl.handle.net/20.500.12182/478

Cooke, B., \& Moon, K. (2015). Aligning “public good” environmental stewardship with the landscape-scale: Adapting MBIs for private 


\section{INSIGHTS INTO REGIONAL DEVELOPMENT}

ISSN 2669-0195 (online) http://jssidoi.org/jesi/

2019 Volume 1 Number 4 (December)

http://doi.org/10.9770/IRD.2019.1.4(1)

land conservation policy. Ecological Economics, 114, 152-158. https://doi.org/10.1016/j.ecolecon.2015.03.027

Davy, B. (2014). Polyrational property: rules for the many uses of land. International Journal of the Commons, 8(2), 472-492. Retrieved from https://www.thecommonsjournal.org/articles/10.18352/ijc.455/

Dye, T. R. (2002). Understanding Public Policy Tenth Edition. New Jersey: Prentice Hall.

Gerber, J., \& Hartmann, T. (2017). The strategic use of time-limited property rights in land-use planning: Evidence from Switzerland. Environment and Planning A, 49(7), 1-20. https://doi.org/10.1177/0308518X17701916

Holmes, J. (2013). The Policy Relevance of the State's Proprietary Power: Lease Tenures in Queensland. Australian Journal of Environmental Management, 3(4), 240-256. https://doi.org/10.1080/14486563.1996.10648361

Janssen-Jansen, L., \& Lloyd, G. (2012). Property booms and bubbles: a demolition strategy - towards a tabula rasa? Journal of Surveying, Construction and Property Citation, 3(2), 1-11. Retrieved from https://hdl.handle.net/11245/1.378679

McCord, J., McCord, M., McCluskey, W., Davis, P. T., McIlhatton, D., \& Haran, M. (2014). Effect of public green space on residential property values in Belfast metropolitan area. Journal of Financial Management of Property and Construction, 19(2), 117-137. Retrieved from https://doi.org/10.1108/JFMPC-04-2013-0008

Ministry of Public Works and People's Housing. (2017). Buku Informasi Statistik. Retrieved from https://eppid.pu.go.id/assets/vendors/ckfinder/userfiles/files/01.Buku Statistik PUPR/BIS 2017.pdf

Ministry of Public Works and People's Housing. (2019). Rumah Tidak Layak Huni. Retrieved from Public Works Agency website: http://datartlh.perumahan.pu.go.id/mdashboard/

Musa, M. M., Amirudin, R. B., Sofield, T., \& Musa, M. A. (2015). Influence of External Environmental Factors on the Success of Public Housing Projects in Developing Countries. Construction Economics and Building, 15(4), 30-44. Retrieved from https://doi.org/10.1108/JFMPC-04-2013-0008

Nasriaty, N. (2016). Implementasi kebijakan rencana tata ruang wilayah di kabupaten mamuju utara. E Jurnal Katalogis, 4(5), 98-108. Retrieved from https://media.neliti.com/media/publications/148124-ID-implementasi-kebijakan-rencana-tata-ruan.pdf

Ogrodowczyk, A. (2015). Spatial aspects of housing policy transformation in Poland after 1989 - example from Lodz. Journal of Economics and Management, 19(1), 137-154. Retrieved from http://cejsh.icm.edu.pl/cejsh/element/bwmeta1.element.desklight-f1ad4a52$\underline{\text { fdd4-4c2d-99f9-e9d69ed61e09 }}$

One Stop Investment Service and Integrated Services Agency. (2018). Laporan Keterangan Pertanggungjawaban Dinas Penanaman Modal dan Pelayanan Terpadu Satu Pintu. Semarang: One Stop Investment Service and Integrated Services Agency.

People's Housing and Settlement Areas Agency. (2018). Data Backlog Kepemilikan Dan Penghunian Rumah di Provinsi Jawa Tengah Tahun 2018. Retrieved from People's Housing and Settlement Areas Agency website: http://si.disperakim.jatengprov.go.id/perumahan/backlog

Public Works Agency. (2018). Berita Acara Badan Koordinasi Penataan Ruang Daerah. Kabupaten Semarang.

Regional Development Planning Agency. (2017). Rencana Pembangunan Jangka Menengah Daerah Kabupaten Semarang. Semarang: Regional Development Planning Agency.

Saifullah. (2016). Formulasi Kebijakan Pelaksana Pelindungan Sempadan Sungai Kabupaten Sukamara. Politika, 7(1), 1-29. Retrieved from

https://www.google.com/search?q=Formulasi+Kebijakan+Pelaksana+Pelindungan+Sempadan+Sungai+Kabupaten+Sukamara\&ie=utf$\underline{8 \& o e=u t f-8 \& c l i e n t=\text { firefox-b-ab }}$

Seo, D., \& Kwon, Y. (2017). In-Migration and Housing Choice in Ho Chi Minh City: Toward Sustainable Housing Development in Vietnam. Sustainability, 9(10), 1-17. https://doi.org/10.3390/su9101738

Yin, R. K. (2003). Case Study Research: Design and Methods (3rd ed.). Thousand Oaks: Sage. 
INSIGHTS INTO REGIONAL DEVELOPMENT

ISSN 2669-0195 (online) http://jssidoi.org/jesi/

2019 Volume 1 Number 4 (December)

http://doi.org/10.9770/IRD.2019.1.4(1)

\section{Aknowledgements}

The authors are thankful for the support from the Ministry of Research and Higher Education of the Republic of Indonesia under 2019-2020 Thesis Research Grant.

Gatot SASONGKO, Dr. is an associated professor at the Faculty of Interdisciplinary of Satya Wacana Christian University. His fields of expertise are labor economics, quantative research and macroeconomic policy. His publications have appeared at various national journals in Indonesia and international journals.

ORCID ID: https://orcid.org/0000-0003-0381-9348

Ina Ariani Restiani HUNGA, Dr. is an assistant professor at the Faculty of Interdisciplinary of Satya Wacana Christian University. Her fields of expertise are sustainability development and gender. Her publications have appeared at various national journals in Indonesia and international journals.

ORCID ID: $\underline{\text { https://orcid.org/0000-0003-1627-2353 }}$

Ardhian Syah Noer JULANA. is a master degree student at the Faculty of Interdisciplinary of Satya Wacana Christian University. His fields of expertise are spatial planning and public policy. His publications have appeared at various national journals in Indonesia.

ORCID ID: https://orcid.org/0000-0003-0832-271X

Yustinus WAHYUDI is a master degree student at the Faculty of Interdisciplinary of Satya Wacana Christian University. His fields of expertise are Microeconomics and applied econometrics. His publications have appeared at various national journals in Indonesia.

ORCID ID: https://orcid.org/0000-0003-1627-2353

Paulus LELIAK is a master degree student at the Faculty of Interdisciplinary of Satya Wacana Christian University. His fields of expertise are regional development and taxation. His publications have appeared at various national journals in Indonesia.

ORCID ID: https://orcid.org/0000-0001-7364-0314

Andrian Dolfriandra HURUTA, M.Si. is a lecturer at the Faculty of Economics and Business of Satya Wacana Christian University. His fields of expertise are macroeconomic policy and applied econometrics. His publications have appeared at various national journals in Indonesia and international journals.

ORCID ID: https://orcid.org/0000-0001-7676-5294

Copyright (C) 2019 by author(s) and VsI Entrepreneurship and Sustainability Center

This work is licensed under the Creative Commons Attribution International License (CC BY).

http://creativecommons.org/licenses/by/4.0/

(c) (7) Open Access 